\title{
Economics and Optimal Frequency of Wyoming Big Sagebrush Control With Tebuthiuron
}

\author{
L. Allen Torell, ${ }^{1}$ Kirk C. McDaniel, ${ }^{2}$ and Carlos G. Ochoa ${ }^{3}$ \\ Authors are ${ }^{1}$ Professor, Department of Agricultural Economics and Agricultural Business, New Mexico State University, \\ Las Cruces, NM 88003; ${ }^{2}$ Professor, Department of Animal and Range Sciences, New Mexico State University, \\ Las Cruces, NM 88003; and ${ }^{3}$ former graduate research assistant, Department of Agricultural Economics and \\ Agricultural Business, New Mexico State University, Las Cruces, NM.
}

\begin{abstract}
The optimal frequency of tebuthiuron ( $N$-[5-(dimetylethyl)-1,3,4-thiadiazol-2yl]- $N, N^{\prime}$-dimethylurea) treatments was investigated for Wyoming big sagebrush (Artemisia tridentata Nutt. ssp. wyomingensis Beetle and Young) when added forage for livestock and wildlife are considered to be the economic benefit of the treatment. Data collected at 8 northwest New Mexico study sites were used to define key relationships for the economic analysis. This long-lived sagebrush control practice was found to be a viable investment for landowners who participate in available cost-share programs. At productive sites, where average herbaceous production increased to over $700 \mathrm{~kg} / \mathrm{h}$ a following big sagebrush control, the economic value of added forage justified the total cost of the herbicide treatment. Tebuthiuron rates higher than $0.5 \mathrm{~kg}$ active ingredient/ha lengthened the expected life of the brush control treatment, but the extended life did not justify the added cost. The threshold abundance of sagebrush needed for economical control was found to be variable, depending on treatment cost, study site, and the economic value of forage. With a 50:50 cost-share arrangement and with forage valued at \$7/AUM, the economic sagebrush canopy threshold from the livestock grazing perspective was estimated to range between $6 \%$ and $14 \%$, depending on site productivity. A second brush control treatment would optimally be implemented before forage production was fully depleted by the recovering brush canopy. Because some native fauna are closely tied to big sagebrush plant communities and benefit from the shrubs' presence, the trade-off in the desired abundance of big sagebrush must be weighed between economic considerations and other resource values of interest.
\end{abstract}

\section{Resumen}

La frecuencia optima de tratamientos con "tebuthiuron" (N-[5-(dimethylethyl)-1,3,4-thiadiazol-2 yl]-N-N'-dimethylurea) fue investigada para "Wyoming big sagebrush" (Artemisia tridentata Nutt. ssp. wyomingensis Beetle and Young) cuando el forraje adicional para ganado y fauna silvestre fue considerado ser el beneficio del tratamiento. Datos obtenidos en ocho sitios de estudio en el Noroeste de Nuevo México fueron utilizados para definir relaciones clave para el análisis económico. Esta práctica de control por tiempo prolongado del "sagebrush" se encontró que sería una inversión económica para los propietarios de la tierra participantes en programas disponibles de costo compartido. En los sitios productivos, donde la producción de forraje incrementó a mas de 700 kg/ ha despues del tratamiento para "sagebrush," el valor económico del forraje adicional justificó el costo total del tratamiento con el herbicida. Concentraciones mayores a $0.5 \mathrm{~kg}$ ingrediente activo/ha extendieron la vida esperada del tratamiento para controlar el arbusto, pero este incremento en la esperanza de vida no justificó el costo adicional. El umbral de "sagebrush" necesario para un económico control se encontró que sería variable dependiendo del costo de tratamiento, sitio de estudio, y el valor del forraje. Con un acuerdo de costo compartido de 50:50 y con forraje valuado en US\$7/UAM, el umbral económico del “big sagebrush” desde la perspectiva del pastoreo para ganado fue estimado que variaría entre $6 \%$ y $14 \%$, dependiendo de la productividad del área. Un segundo tratamiento para controlar el arbusto podría ser óptimamente implementado antes de que la producción forrajera fuera completamente reducida por la recuperación de la cobertura vegetal del arbusto. Dado que alguna fauna nativa esta muy ligada a las comunidades de "big sagebrush" y se beneficia de la presencia de estos arbustos, el intercambio en la abundancia deseada de "big sagebrush" debe ser sopesado entre consideraciones económicas y el valor de interés de otros recursos.

Key Words: Artemisia tridentata Nutt. ssp. wyomingensis Beetle and Young, economic threshold, economics of brush control, timing of brush control, optimal asset replacement, Faustmann model

\section{INTRODUCTION}

The economics of controlling big sagebrush (Artemisia tridentata Nutt.) has received little recent attention. Past economic

Research was supported by New Mexico State University's Agricultural Experiment Station. Correspondence: Kirk C. McDaniel, Department of Animal and Range Sciences, PO Box 30003, MSC 3-I, New Mexico State University, Las Cruces, NM 88003. Email: kmcdanie@nmsu.edu

Manuscript received 5 January 2004; manuscript accepted 9 July 2004. analyses focused on forage response and added livestock grazing capacity as reasons to control the shrub. Yet other benefits from big sagebrush control have long been recognized. As noted by Hyder and Sneva (1956, p. 34), "The economics of brush control must be determined by the amount of forage and meat products gained; however, the principal objective in brush control should be an upgrade in range condition."

Recent justification for big sagebrush control on federal land has emphasized rangeland health and improved rangeland condition (Olson et al. 1994). Perceived public benefits from con- 
trolling big sagebrush, including enhanced species diversity, watershed stability, and better habitat for wildlife, are reasons given by the Bureau of Land Management (BLM) in northwestern New Mexico for implementing this practice. As noted by Olson et al. (1994), resource managers from the Farmington BLM District now strive to thin Wyoming big sagebrush (Artemisia tridentata Nutt. ssp. wyomingensis Beetle and Young, the principal subspecies in this region) so as to have a mosaic of shrubs, grasses, and forbs and believe that this diverse plant composition provides optimum conditions for livestock grazing, wildlife habitat, and protection of watersheds.

We recognize the importance of including and evaluating trade-offs among multiple products potentially produced from rangelands, especially with the increasing emphasis on ecological and environmental resource values. However, this assessment is not possible without additional quantification of ecological and economic trade-offs, economic values, and production relationships. Given this limitation, we follow the procedure used by Lee et al. (2001) in an economic evaluation of brush control treatments for enhanced off-site water yields in Texas. We assume that a land manager's participation in a brush control program will depend on expected economic consequences. We first evaluate the economics of Wyoming big sagebrush control, assuming a 50:50 cost-share split between participating ranchers and federal, state, and county agencies. Next, we compute the break-even cost of the brush control treatment from the rancher's perspective. The difference between the total cost of the sagebrush control project and the rancher's break-even cost must be contributed by state, county, or federal funds to realize rancher participation. Further, unmeasured benefits to nonlivestock entities must exceed this subsidy amount if the brush control project is to be a profitable expenditure of public funds. Looking at it from the rancher's perspective, we compute the economically optimal time to retreat the big sagebrush canopy. The economic threshold abundance of Wyoming big sagebrush necessary to economically justify control is also computed. How the optimal timing of treatments and the optimal threshold of brush to treat would change if trade-offs with other nonlivestock resource values were considered is also discussed.

The analysis uses long-term field studies in northwestern New Mexico, presented as a companion paper (McDaniel et al. 2005), to quantify necessary relationships for the economic evaluation. The economic analysis follows a review of the many perceived benefits and trade-offs from controlling big sagebrush.

\section{BENEFITS AND TRADE-OFFS OF BIG SAGEBRUSH CONTROL}

By far, the most recognized and documented benefit of controlling big sagebrush is added forage production. It is widely reported that average annual production of grasses and forbs increases 2-4 times following control of Wyoming big sagebrush (see the companion paper by McDaniel et al. [2005] for a review of Wyoming big sagebrush overstory-understory relationships). Along with an increase in grazing capacity and increases in animal performance, livestock production per hectare has also increased. Sneva (1972) monitored forage and animal production on a big sagebrush-bunchgrass range near the Squaw Butte Experiment Station at Burns, Oregon, and reported that, with brush control, beef production per hectare increased 2.3 times $(17.3 \mathrm{~kg} / \mathrm{ha}$ vs. $7.5 \mathrm{~kg} / \mathrm{ha})$. Similarly, Hyatt (1966) reported in a review of costs and benefits from big sagebrush control on his Wyoming ranch that average forage production increased 3.3 times and sale weights increased $4.5 \mathrm{~kg} / \mathrm{lamb}$ and $7.3 \mathrm{~kg} / \mathrm{calf}$.

While rangeland carrying capacity usually increases following big sagebrush control, increased livestock numbers are not always allowed or warranted. Under cost-share agreements with the Farmington and Albuquerque BLM districts, the land agency typically pays $85 \%$ of treatment costs. In some cases it pays $100 \%$. Livestock numbers are usually not increased on federal allotments following big sagebrush control, at least not in the short term (R. Sanchez and E. Williams, BLM, personal communication, 3 December 2001). A partial justification for sagebrush control is that the stocking rate on a federal allotment can be maintained nearer grazing preference. Sagebrush control helps the BLM avoid potential conflict and lawsuits with permittees and environmentalists because positive steps are taken to reduce grazing pressure but without forcing major herd reductions. Forgoing herd reductions and increased animal performance following brush control are important incentives used to encourage rancher participation in BLM big sagebrush control programs and broader allotment management plans (E. Williams, BLM, personal communication, 3 December 2001).

The benefit of negating the need for herd reductions is not new. Nearly 40 years ago, Hyatt (1966) reported that with big sagebrush control, cross fencing, and water developments, reductions in allowed grazing that had previously been made on his Wyoming allotments were restored within 5 years of cooperative range improvement projects. Similarly, forestalling the need for controversial grazing reductions was a primary benefit of the 11-year (1962-1972) Vale Rangeland Rehabilitation Program initiated on BLM lands in eastern Oregon (Bartlett et al. 1988).

Watershed benefits are increasingly recognized as a reason for big sagebrush control on BLM land in New Mexico (R. Sanchez, personal communication, 3 December 2001). Perceived benefits include increased off-site water yield, increases in the amount of precipitation reaching the ground and thus available to recharge groundwater and aquifers (Hull and Klomp 1974; West and Gifford 1976), and protection against soil erosion. Increased water flow from springs, seeps, and stream channels following control of big sagebrush has been noted, especially when shrubs are controlled in deep, fertile valley bottoms (Anonymous 1962; Hyatt 1966). Yet little research documents these observations, especially at the watershed level. Sturges (1983) reported that, following big sagebrush control, the response of the soil water regime was inversely related to the response in herbaceous production. This suggests that much of the added water from sagebrush control is used in producing herbaceous standing crop, and thus added forage production, not water yield, was the primary measured benefit of the brush control practice.

Decreased sedimentation from soil erosion has been documented within 3 years of tebuthiuron treatment of big sagebrush near Cuba, New Mexico (Rone 2001). Chemical big sagebrush treatment was found to reduce sediment concentrations from 5 to 8 times on treated areas compared to untreated plots. How- 
ever, how the measured reductions in soil water depletion and diminished sediments in runoff translates into reduced soil erosion, recharged groundwater, and enhanced and purified water leaving the watershed has not been determined.

Other noted benefits of big sagebrush control include easier livestock handling and movement (Tanaka and Workman 1988). Further, according to Olson et al. (1994), large herbivores, including cattle, elk, deer, and antelope, congregate on areas where big sagebrush has been controlled and, as a result, may move away from riparian areas. There are, however, uncertainties regarding wildlife benefits from big sagebrush control. Correlations have been drawn between declines in big sagebrush and downward trends in certain wildlife populations, most notably the western sage grouse (Centrocercus urophasianus; Connelly et al. 2000). Further research is needed to determine the relationship of western sage grouse and other faunal species to the presence of varying spatial and temporal levels of big sagebrush and understory vegetation.

\section{ECONOMIC MODEL DEVELOPMENT}

Following economic models presented by Torell and McDaniel (1986) and by Watts and Wambolt (1989), the economic analysis of alternative tebuthiuron treatments computes the net present value (NPV) of livestock grazing returns under 2 alternatives. The first alternative considers only the NPV of a single brush control treatment. Under this scenario, the standard economic analysis computes the NPV of the range improvement practice as

$$
\mathrm{G}(\mathrm{S})=\sum_{t=1}^{S} f(t) e^{-r t}-K
$$

where

$$
\begin{aligned}
\mathrm{G}(\mathrm{S})= & \text { the NPV of the income stream calculated over } \\
& \text { the expected or assumed S-year treatment life, } \\
f(t)= & \text { additional livestock revenue expected to be } \\
& \text { realized at time } t, \\
e= & \text { Euler's number }(2.71828 \ldots), \\
r= & \text { the discount rate compounded continuously over } \\
& \quad \text { time } t, \text { and } \\
K= & \text { the cost of treatment. }
\end{aligned}
$$

As noted by McDaniel et al. (2005), because of seedling recruitment, Wyoming big sagebrush will return to tebuthiuron treated areas. As such, the calculated NPV of additional livestock revenue resulting from big sagebrush control is assumed to have a finite life of length $S$. At time $S$, livestock production benefits from the treatment will have been exhausted, and $\mathrm{G}(\mathrm{S})$ will be at a maximum. Treated and untreated big sagebrush canopy covers will once again be similar but not necessarily the same. Positive economic benefits from the brush control treatment may still exist if wildlife habitat or other resource values are enhanced with a reduced sagebrush canopy.

If NPV is positive, the discounted benefits of the big sagebrush control treatment exceed treatment costs. Big sagebrush control following this treatment prescription would be recommended, provided alternative investments and control strategies would not yield a higher NPV (Workman 1986). If NPV is negative, the range improvement practice is not economically justified by livestock production alone, and a reduced cost through cost-share programs would be required to encourage rancher participation. This assumes that other unmeasured societal benefits to the rangeland resource justify taxpayer expenditures for the subsidized brush control program.

Sagebrush canopy (C) on treated areas is expected to increase with time. As such, the second management alternative recognizes that, if the big sagebrush control project is profitable, there is an economically optimal time to retreat the brush canopy. The model used to make this replacement decision is based on optimum rotation theory developed by Faustmann (1849) for forests and discussed in detail by Perrin (1972). As presented by Perrin (1972), assuming the response from each treatment is identical and relating back to equation 1 , the optimal replacement age will be that $S$, call it $S^{*}$, that maximizes the NPV of all future brush control treatments, and will occur where

$$
\mathrm{F}(\mathrm{S})=\frac{1}{1-e^{-r s}} \sum_{t=1}^{S} f(t) e^{-r t}-K
$$

is maximized. This maximum will generally occur before added revenue from the current asset is fully depleted. $F(S)$ is the NPV of the infinite income stream calculated with an S-year treatment rotation. At the optimal retreatment age $\left(\mathrm{S}^{*}\right)$, big sagebrush canopy cover will have progressed back to some level, and this sagebrush canopy $\left(\mathrm{C}^{*}\right)$ is the optimal canopy cover to treat. $\mathrm{C}^{*}$ is the profit-maximizing economic threshold abundance of big sagebrush that would justify sagebrush control. This optimal treatment age and the corresponding economic threshold level of big sagebrush are rarely computed because long-term data are generally not available to define the expected time path of brush invasion. The standard economic analysis of brush control projects is based on estimates of added grazing capacity, but the underlying overstory-understory relationship and the rate of brush reinvasion, while implied, remains undefined in the typical economic analysis (Workman 1986).

With definition of $f(t)$, treatment cost $(K)$, and discount rate $(r)$, the NPV of the single investment can be computed using equation 1 and the NPV over all future investments using equation 2. $\mathrm{S}^{*}$ can be determined by computing $\mathrm{F}(\mathrm{S})$ for alternative $S$, searching for the $S$ that maximizes discounted NPV of the income stream.

\section{METHODS AND ECONOMIC MODEL ASSUMPTIONS}

\section{Herbage Response and Utilization}

Combining estimates of overstory-understory relationships with estimates of how the Wyoming big sagebrush canopy is expected to reinvade over time, Figure 4 in the companion paper by McDaniel et al. (2005) provides a projection of average annual perennial grass production (relative to untreated areas) in the years following tebuthiuron control at 8 study sites in northwestern New Mexico. Projections are made for alternative tebuthiuron treatment rates when reinvasion of big sagebrush was found to be different by herbicide rate.

Added available forage for livestock and wildlife grazing was estimated assuming that proper grazing would allow re- 
Table 1. Assumptions of the baseline economic analysis.

\begin{tabular}{|c|c|}
\hline Assumption & Assumed level \\
\hline Value of added forage & $\$ 7 / A U M$ \\
\hline Cost of tebuthiuron treatment $(\$ / \mathrm{ha})^{1}$ & $\begin{array}{l}K=\$ 12.35+\$ 76.50 * \text { rate, where rate } \\
\text { is the tebuthiruon active ingredient } \\
\text { applied in } \mathrm{kg} / \mathrm{ha}\end{array}$ \\
\hline Cost share & Rancher pays $50 \%$ of treatment costs \\
\hline Tebuthiuron treatment rate & $0.5 \mathrm{~kg} / \mathrm{ha}$ \\
\hline Discount rate & $7 \%$ \\
\hline Grazing deferment & $\begin{array}{l}\text { Required 2-year growing season } \\
\text { deferment but winter grazing allowed } \\
\text { at pretreatment levels }\end{array}$ \\
\hline Proper grazing use & $\begin{array}{l}\text { Harvest } 50 \% \text { of additional herbaceous } \\
\text { production }\end{array}$ \\
\hline AUM definition & $354 \mathrm{~kg} / \mathrm{AUM}$ \\
\hline
\end{tabular}

${ }^{1}$ Cost was estimated for the baseline analysis based on average 2002 commercial herbicide costs.

moval of half the added grass production. Animal unit months of grazing added at time $t$ by brush control were multiplied by the estimated leasehold value of the AUM to estimate added revenue $(\$ /$ ha $)$ as defined by $f(t)$ in equation 1 .

\section{Model Assumptions}

Cost of big sagebrush control will depend on the herbicide rate applied and the number of acres treated. Further, aerial application costs will be less if an airport or suitable landing strip is nearby. A representative of Dow Agro-Sciences (M. Savage, 25 June 2002) estimated average 2002 commercial costs for tebuthiuron of $\$ 12.35 / \mathrm{ha}$ for aerial application and $\$ 76.50 / \mathrm{kg}$ of tebuthiuron active ingredient applied. This was the treatment cost assumed in the baseline analysis, but treatment costs vary considerably. Costs were reduced to $\$ 10.32 /$ ha for aerial application and $\$ 61.89 / \mathrm{kg}$ for large blocks of land treated by BLM in northwestern New Mexico during 2000-2001 (R. Sanchez, unpublished data, Farmington BLM District, 3 December 2001).

Various cost-share funds are used to control big sagebrush in northwestern New Mexico, including Environmental Quality Incentive Program funds with the Natural Resource Conservation Service (NRCS), Farm and Ranch Improvement Funds through San Juan County, and cost-share agreements with BLM on federal lands. The typical arrangement is for NRCS to pay $65 \%$ of big sagebrush control costs, and the participating rancher pays the rest. The NRCS will pay up to $75 \%$ if the site is a geographic priority area as defined by their guidelines (G. Chavez and D. Branch, NRCS, personal communication, 3 December 2001). The San Juan County cost-share program requires a 50:50 cost split (G. Hawthorn, County Extension Service, personal communication, 3 December 2001). On federal lands, the total treatment cost is paid by BLM in some cases, but the more common arrangement is for the participating rancher to pay $15 \%$ of costs. The midpoint $50: 50$ cost split was assumed in the baseline economic analysis (Table 1).

Different methods can be used to estimate the economic value of rangeland forage. Bartlett et al. (2002) reported that the average private land lease rate when multiplied by $70 \%$ yields a reasonable estimate of forage value. Data reported by
USDA/NASS (2002) estimated that the average 2002 forage lease rate in New Mexico was \$10.50/AUM, which suggests a forage value of about $\$ 7 / A U M$. This forage value was used for the baseline analysis. An interest rate of $7 \%$ was used to discount future economic returns.

Minimal increases in grass production on treated areas would be expected during the initial 2 years following tebuthiuron treatment (McDaniel and Balliette 1986). Thus, 2 years of growing-season deferment was specified in the economic analysis. It was assumed that during these 2 years the area could be grazed at pretreatment levels during the winter. This assumption is consistent with the grazing management requirement specified in various cost-share programs (E. Williams, BLM, personal communication, 3 December 2001). The assumption implies no increase or decrease in AUM availability during the first 2 years of the economic analysis.

A sensitivity analysis was performed to evaluate how results changed when tebuthiuron treatment rates, treatment costs and/or cost-share arrangements, forage value, and discount rate were changed. Chemical costs increased at higher treatment rates. Thus, the sensitivity analysis for treatment rate considers site-specific differences in forage response over time by herbicide treatment rate and the increased cost of the chemical. Alternative tebuthiuron treatment rates considered varied by site depending on the treatments implemented at that site (McDaniel et al. 2005).

Two alternative forage values were considered in the sensitivity analysis: $\$ 5$ and \$10/AUM. Similarly, 2 alternative discount rates, $5 \%$ and $9 \%$, were also evaluated. How economic results changed with different treatment costs and forage values was evaluated by computing break-even costs $(\$ / h a)$ for the brush control treatment. When the calculated NPV is negative, this break-even cost $(\$ / \mathrm{ha})$ is the required amount of nonlivestock value needed to economically justify the brush control from society's perspective, assuming the rancher is allowed full grazing use and benefit of the added forage. The grazing benefit might be added animals or forgoing reductions in grazing that would have otherwise been required.

\section{RESULTS}

\section{Baseline Economic Conditions}

Assuming a $0.5-\mathrm{kg} / \mathrm{ha}$ tebuthiuron rate, Table 2 presents the NPV of economic returns computed for the various study sites under baseline conditions detailed in Table 1. Reported NPV values are evaluated at the maximum values of $G(S)$ and $F(S)$, respectively. The internal rate of return (IRR) is calculated for a single brush control treatment. The columns labeled "Estimated treatment life" and "Optimal treatment frequency" define when NPV from the single treatment and NPV from the infinite treatments would be maximized.

Study sites with higher NPV corresponded in ranking to sites with higher herbaceous understory response $(\mathrm{McDaniel}$ et al. 2005, Fig. 4). Forage response from Wyoming big sagebrush control was the major factor influencing the economics of sagebrush control for enhanced livestock production. Navajo City had the highest NPV and was also the most productive site, followed by the Tres Piedras Middle site. The Taos and Tres Piedras North sites had a negative NPV and were not economical to treat under baseline economic conditions. Because big 
Table 2. Net present value (NPV), optimal frequency of retreatment $\left(\mathrm{S}^{\star}\right)$, and optimal sagebrush canopy to control $\left(\mathrm{C}^{\star}\right)$ under baseline economic conditions by study site.

\begin{tabular}{|c|c|c|c|c|c|c|c|}
\hline Study site & $\begin{array}{l}\text { NPV of single } \\
\text { treatment } \\
G(S)(\$ / h a)\end{array}$ & $\begin{array}{l}\text { Estimated } \\
\text { treatment life } \\
\text { (S) (y) }\end{array}$ & $\begin{array}{c}\text { Average sagebrush } \\
\text { canopy of } \\
\text { untreated areas }\end{array}$ & $\begin{array}{l}\text { NPV of infinite } \\
\text { treatments } \\
F\left(S^{\star}\right)(\$ / h a)\end{array}$ & $\begin{array}{l}\text { Internal rate } \\
\text { of return }\end{array}$ & $\begin{array}{l}\text { Optimal treatment } \\
\text { frequency } \\
\left(\mathrm{S}^{\star}\right)(\mathrm{y})\end{array}$ & $\begin{array}{c}\text { Optimal sagebrush } \\
\text { canopy to treat } \\
\left(C^{\star}\right)\end{array}$ \\
\hline Bloomfield & $\$ 16.54$ & 44 & $13 \%$ & $\$ 18.09$ & $12.2 \%$ & 32 & $6 \%$ \\
\hline Cedar Hills & 8.97 & 25 & $15 \%$ & 11.93 & $11.2 \%$ & 18 & $8 \%$ \\
\hline Gobernador & 10.28 & 43 & $15 \%$ & 11.73 & $11.0 \%$ & 26 & $10 \%$ \\
\hline Taos & -8.13 & 17 & $24 \%$ & -8.38 & $1.6 \%$ & Do not treat & \\
\hline Navajo City & 40.32 & 39 & $22 \%$ & 49.41 & $19.8 \%$ & 21 & $10 \%$ \\
\hline Tres Piedras North & -1.07 & 50 & $20 \%$ & -1.10 & $6.8 \%$ & Do not treat & \\
\hline Tres Piedras Middle & 30.36 & 50 & $18 \%$ & 32.88 & $15.4 \%$ & 33 & $9 \%$ \\
\hline Tres Piedras South & 11.77 & 44 & $20 \%$ & 12.99 & $11.1 \%$ & 30 & $14 \%$ \\
\hline
\end{tabular}

sagebrush control treatments are long lived, and with a positive interest rate that discounts future returns, the NPV of the first treatment, $G(S)$, was not greatly different from NPV of the infinite series of treatments, $F\left(S^{*}\right)$.

Treatment life was considered to be that year when all potential forage-response benefits from the chemical treatment were exhausted. This point was defined to occur when estimated average grass production on the treated area was projected to move within $5 \mathrm{~kg} / \mathrm{ha}$ of the untreated control plots (McDaniel et al. 2005, Fig. 4). Treatment life ranged from 17 to 50 years (Table 2 ).

Herbaceous production on treated and untreated areas is estimated to be similar at time S (McDaniel et al. 2005, Fig. 4). The optimal big sagebrush canopy cover to treat $\left(\mathrm{C}^{*}\right)$ ranged from $6 \%$ at the Bloomfield site to $14 \%$ at the Tres Piedras South site. At all sites that were economically feasible to treat, $C^{*}$ was far less than the average big sagebrush canopy cover of adjacent untreated areas, nearly half as much in some cases. The big sagebrush canopy would optimally be treated just as the lower asymptote of the overstory-understory curve is approached (McDaniel et al. 2005, Fig. 3). The estimated optimal canopy of brush to treat was generally less than that reported by Bastian et al. (1995). These authors concluded that if big sagebrush control cost $\$ 26.54 /$ ha and forage was valued at $\$ 6.13 /$ AUM (similar to the assumption used in this study for the $0.5-\mathrm{kg} / \mathrm{ha}$ herbicide rate with $50 \%$ cost share), then the threshold abundance of brush canopy to treat was $12 \%$ if the treatment lasts 25 years.

\section{Sensitivity Analysis}

Herbicide Treatment Rate. McDaniel et al. (2005) found that higher tebuthiuron rates generally extended treatment life. Economic results indicate, however, that the extended treatment life does not justify the added cost of the herbicide. As indicated by the NPV ranking in Table 3, lower rates of tebuthiuron were always more profitable.

Discount Rate. As would be expected, NPV was highest for the lowest discount rate considered, 5\% (Fig. 1). The Tres Piedras North site moved from a negative NPV to a positive NPV when the discount rate was reduced from $7 \%$ to $5 \%$. NPV remained positive for all previously profitable sites when the discount rate increased to $9 \%$, but the investment approaches a break-even situation with this higher discount rate (Fig. 1). The calculated IRR ranged from $11 \%$ to $20 \%$ at those sites initially determined to be economically feasible for brush control (Table 2).

Because a higher discount rate decreases the present value of future income, a higher discount rate generally shortens optimal replacement age. However, as shown by Perrin (1972),

Table 3. Net present value (NPV), optimal frequency of treatment $\left(\mathrm{S}^{\star}\right)$, and optimal sagebrush canopy to treat $\left(\mathrm{C}^{\star}\right)$ with alternative tebuthiuron treatment rates by study site. ${ }^{1}$

\begin{tabular}{|c|c|c|c|c|}
\hline Study site & $\begin{array}{l}\text { Treatment } \\
\text { rate } \\
(\mathrm{kg} / \mathrm{ha})\end{array}$ & $\begin{array}{l}\mathrm{NPV} \text { of } \\
\text { infinite } \\
\text { treatments } \\
\mathrm{F}\left(\mathrm{S}^{*}\right)\end{array}$ & $\begin{array}{c}\text { Optimal } \\
\text { treatment } \\
\text { frequency } \\
\left(\mathrm{S}^{\star}\right)(\mathrm{y})\end{array}$ & $\begin{array}{l}\text { Optimal } \\
\text { sagebrush } \\
\text { canopy to } \\
\text { treat }\left(\mathrm{C}^{\star}\right)\end{array}$ \\
\hline \multirow[t]{3}{*}{ Bloomfield } & 0.5 & $\$ 18.09$ & 32 & $6 \%$ \\
\hline & 0.8 & 5.41 & 36 & $7 \%$ \\
\hline & 1.1 & -6.61 & Do not treat & \\
\hline \multirow[t]{3}{*}{ Cedar Hills } & 0.5 & 11.93 & 18 & $8 \%$ \\
\hline & 0.8 & 2.75 & 28 & $11 \%$ \\
\hline & 1.1 & -5.32 & Do not treat & \\
\hline \multirow[t]{3}{*}{ Gobernador } & 0.5 & 11.73 & 26 & $10 \%$ \\
\hline & 0.8 & 1.22 & 50 & $14 \%$ \\
\hline & 1.1 & -9.44 & Do not treat & \\
\hline \multirow[t]{3}{*}{ Taos } & 0.5 & -8.38 & Do not treat & \\
\hline & 0.8 & -15.19 & Do not treat & \\
\hline & 1.1 & -25.01 & Do not treat & \\
\hline \multirow[t]{4}{*}{ Navajo City } & 0.4 & 54.39 & 20 & $9 \%$ \\
\hline & 0.5 & 49.41 & 21 & $10 \%$ \\
\hline & 0.6 & 44.55 & 20 & $10 \%$ \\
\hline & 0.9 & 29.32 & 20 & $10 \%$ \\
\hline \multirow[t]{4}{*}{ Tres Piedras North } & 0.4 & 2.70 & 30 & $17 \%$ \\
\hline & 0.5 & -1.10 & Do not treat & \\
\hline & 0.6 & -0.69 & Do not treat & \\
\hline & 0.7 & -8.58 & Do not treat & \\
\hline \multirow[t]{4}{*}{ Tres Piedras Middle } & 0.3 & 41.39 & 32 & $9 \%$ \\
\hline & 0.4 & 34.55 & 27 & $9 \%$ \\
\hline & 0.5 & 32.88 & 33 & $9 \%$ \\
\hline & 0.6 & 25.60 & 28 & $10 \%$ \\
\hline \multirow[t]{4}{*}{ Tres Piedras South } & 0.4 & 17.37 & 29 & $14 \%$ \\
\hline & 0.5 & 12.99 & 30 & $14 \%$ \\
\hline & 0.7 & 4.42 & 35 & $17 \%$ \\
\hline & 0.9 & -3.64 & Do not treat & \\
\hline
\end{tabular}

${ }^{1}$ Treatment rate was varied, which changed the projected future increase in AUMs available for grazing and the treatment cost. All other economic variables were as defined in Table 1. 


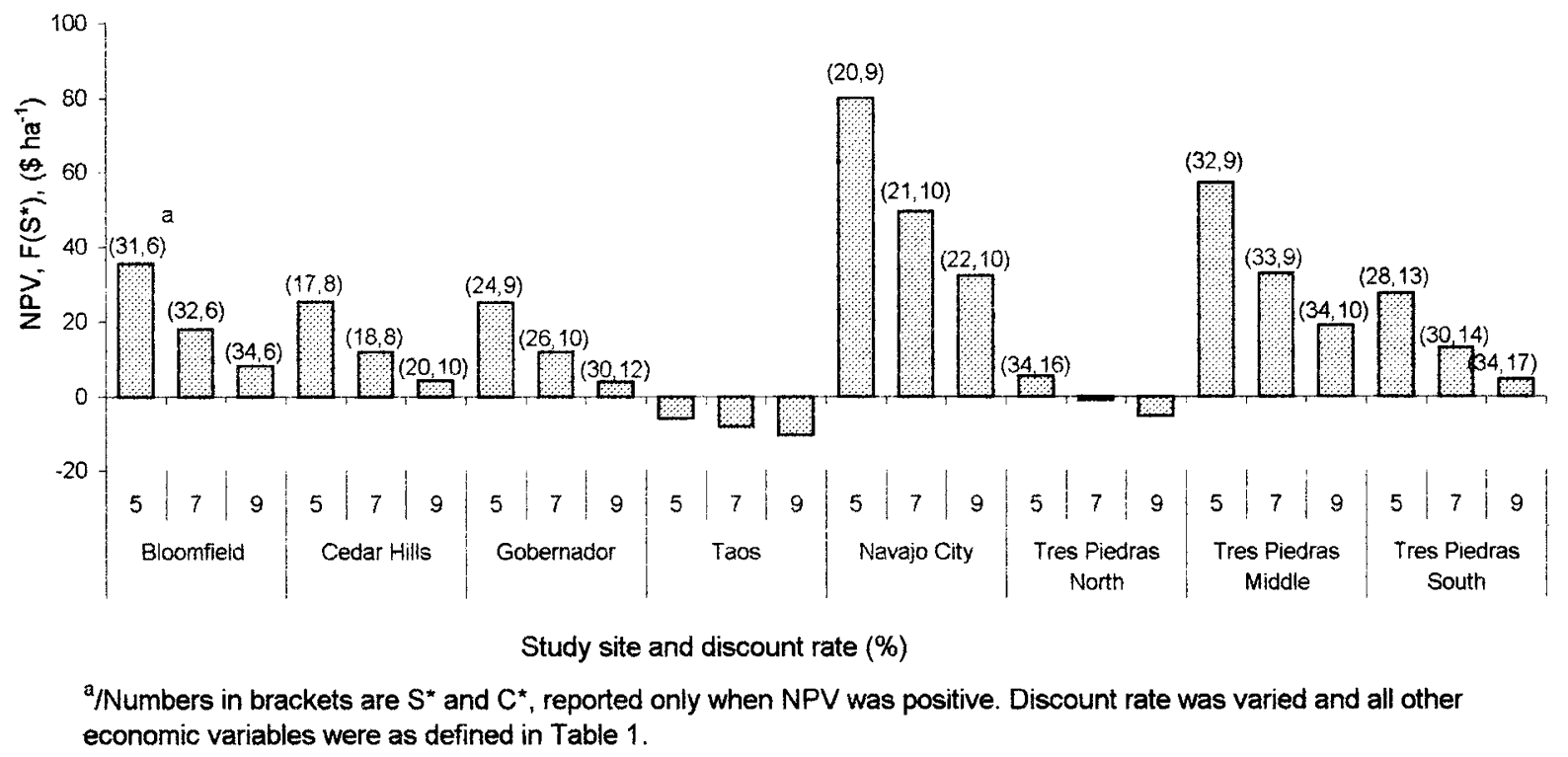

Figure 1. Net present value (NPV), optimal frequency of treatment $\left(S^{\star}\right)$, and optimal sagebrush canopy to treat $\left(C^{\star}\right)$ at alternative discount rates by site.

optimal replacement age can be either shortened or extended depending on definition of the revenue function, $f(t)$, and the level of the discount rate. In this application, optimal replacement age was increased slightly as discount rate increased. Correspondingly, the threshold big sagebrush canopy cover to treat either stayed the same or increased slightly as discount rate increased (Fig. 1).

A positive discount rate means that economic benefits in the immediate future are more highly valued than benefits in the distant future. Given this, selection of the discount rate may influence the economically optimal herbicide rate to apply because more forage production benefits occurred in the distant future with higher tebuthiuron rates (McDaniel et al. 2005, Fig. 4). A sensitivity analysis on discount rate did not indicate this was the case. Reducing the discount rate to nearly zero did not alter the ranking of economic results shown in Table 3; lower chemical treatment rates continued to maximize NPV.

\section{Break-Even Cost-Share Arrangements}

An alternative way to evaluate how treatment cost and forage value affects the economics of brush control is to compute a break-even treatment cost, that is, compute the maximum amount a land manager could afford to spend on the brush control treatment and just break even on the investment (i.e., the $K$ in equation 2 that forces NPV of $\mathrm{F}\left[\mathrm{S}^{*}\right]=0$ ). Break-even costs are presented in Table 4 for each study site at alternative treatment rates of $0.5 \mathrm{~kg} / \mathrm{ha}$ or less and for forage values of $\$ 5$, $\$ 7$, and \$10/AUM.

As discussed previously, typical cost-share arrangements vary but generally are 15:85 (15\% rancher:85\% land agency) on BLM lands, 35:65 with NRCS, and 50:50 with San Juan County. Comparing these levels to the break-even cost shares computed in Table 4, it can be seen that, with the exception of the relatively unproductive Taos and Tres Piedras North sites, all sites treated with herbicide rates of $0.5 \mathrm{~kg} / \mathrm{ha}$ or less would yield a positive return to rancher investment if forage was valued at \$7/AUM. At the relatively productive Navajo City and Tres Piedras Middle sites, where big sagebrush control increased average grass yield by over $700 \mathrm{~kg} / \mathrm{ha}$ (McDaniel et al. 2005, Fig. 3), the total $\$ 50.60 /$ ha cost of the tebuthiuron treatment would be justified from forage production benefits alone. The full cost of the brush control treatment would be covered for most of the study sites if forage value increased to \$10/AUM.

Break-even cost-share arrangements vary widely depending on the productivity of the rangeland site and assumed forage value (Table 4). This variability and a general need for costshare programs to encourage rancher participation in brush control programs was also found by Lee et al. (2001) in the Edwards Plateau area of Texas.

The question we did not address is whether unmeasured benefits of improved wildlife habitat, watershed improvement, enhanced species diversity, reduced soil erosion, and other resource values justify public expenditures on big sagebrush control. ${ }^{1}$ As shown in Table 4 , the residual amount not covered by livestock production returns range from zero at the Navajo City and Tres Piedras Middle sites to about \$36/ha at the Taos site when forage is valued at \$7/AUM.

It is interesting to note that if a rancher must pay the breakeven cost so that the calculated NPV of the investment is zero, the optimal time to retreat the brush stand will always occur when grass-yield response from the treatment is fully depleted, which is the defined treatment life in Table 2. By comparison, if the rancher pays no part of treatment cost, and assuming authorization is given by the cooperating land agency for full grazing use of the added forage from the brush control, the optimal

${ }^{1}$ The argument is made that, without subsidies, conservation practices like brush control and soil erosion deterrents will be underfunded by the private investor and therefore that conservation practices should be subsidized to reduce costs and encourage investment. In addition to this "market failure" argument for subsidies, the need to redistribute income and maintain family farms has also been used as a rationale for US agricultural programs. An interesting review of the economic rationale of subsides is provided by Pasour (1990). 
frequency of treatment (from the rancher's perspective) would be to retreat the brush just as forage production begins to decline from peak levels. The optimal time to treat and the corresponding economic threshold abundance of big sagebrush justifying control vary between these two extremes, depending on site productivity, treatment cost, forage value, and discount rate. As is true of all economic studies, there is no single threshold level of big sagebrush that economically justifies control.

\section{DISCUSSION AND MANAGEMENT IMPLICATIONS}

Site potential and its influence on realized grass yield response following Wyoming big sagebrush control were the main factors influencing the economics of tebuthiuron control. Sites that were most profitable to treat produced an average of about $200 \mathrm{~kg} / \mathrm{ha}$ of perennial grasses before treatment. On these areas, average grass yield following brush control increased to $600 \mathrm{~kg} / \mathrm{ha}$ or more (McDaniel et al. 2005, Fig. 4). Hyder and Sneva (1956) concluded that sagebrush-bunchgrass range in fair condition with deep-rooted bunchgrasses yielding about $168 \mathrm{~kg} / \mathrm{ha}$ is suited for profitable improvement with chemical big sagebrush control. They felt that grasses should be frequently distributed so that one can walk along stepping from plant to plant without too many misses, and we agree with this general guideline. For example, untreated areas at the Taos and Tres Piedras North sites produced well below the Hyder and Sneva (1956) guideline, and in our analysis, were not profitable to treat without very generous cost-share allocations or high forage value.

Treatment life influences the economics of big sagebrush control, but in our study it was not nearly as important as the observed response of the herbaceous understory. Tebuthiuron treatments at all study sites, with the exception of Taos, were found to have a treatment life of at least 25 years and more likely $35-50$ years. Economically optimal retreatment of the brush canopy would occur before this maximum treatment life, varying by site and cost-share arrangement.

The BLM in northwestern New Mexico has concluded that thinning big sagebrush with low rates of tebuthiuron $(0.3 \mathrm{~kg} / \mathrm{ha})$ better meets the objective of having a mosaic of shrubs, grasses, and forbs (Olson et al. 1994). Sampling at study sites using rates below $0.5 \mathrm{~kg} / \mathrm{ha}$ was limited in the McDaniel et al. (2005) study, and though lower tebuthiuron rates are now commonly applied, big sagebrush kill has been more variable at these low rates (Whitson et al. 1988; McDaniel et al. 1992). If the big sagebrush control objective is added forage for livestock and wildlife, the estimated $\$ 5-\$ 10 /$ ha increase in NPV by reducing rates below a $0.5-\mathrm{kg} / \mathrm{ha}$ rate may not be realized given the increased variability of treatment success. More research is needed to evaluate treatment longevity and consistency of control at low tebuthiuron rates. Low tebuthiuron rates are clearly more desirable if only a minimal reduction of the big sagebrush canopy is desired.

Guidelines developed by Connelly et al. (2000) suggest no sagebrush control or minimal reductions of the sagebrush canopy for rangelands where sage grouse habitat is of key concern. They describe productive sage grouse habitat to have relatively dense stands of sagebrush $(15 \%-25 \%$ canopy $)$ with an accompanying productive understory of grasses and forbs. In our companion paper (McDaniel et al. 2005, Fig. 3), we found
Table 4. Break-even treatment costs and cost-share arrangement by study site for alternative forage values and for $0.5-\mathrm{kg} / \mathrm{ha}$ or less tebuthiuron rate.

\begin{tabular}{|c|c|c|c|c|c|}
\hline Site & $\begin{array}{c}\text { Herbicide } \\
\text { rate } \\
\text { (kg active } \\
\text { ingredient/ha) }\end{array}$ & $\begin{array}{c}\text { Total } \\
\text { treatment } \\
\text { cost } \\
(\$ / \mathrm{ha})\end{array}$ & $\begin{array}{l}\text { Break-even } \\
\text { cost }^{1} \\
(\$ / \mathrm{ha})\end{array}$ & $\begin{array}{l}\text { Shortfall/ } \\
\text { excess } \\
\text { (\$/ha) }\end{array}$ & $\begin{array}{c}\text { Break-even } \\
\text { cost } \\
\text { share } \\
(\%)\end{array}$ \\
\hline \multicolumn{6}{|l|}{$\$ 5 / A U M$ forage value } \\
\hline Bloomfield & 0.5 & 50.60 & 29.88 & -20.72 & $59: 41$ \\
\hline Cedar Hills & 0.5 & 50.60 & 24.48 & -26.12 & $48: 52$ \\
\hline Gobernador & 0.5 & 50.60 & 25.41 & -25.19 & $50: 50$ \\
\hline Taos & 0.5 & 50.60 & 12.27 & -38.33 & $24: 76$ \\
\hline \multirow[t]{2}{*}{ Navajo City } & 0.4 & 42.95 & 46.87 & 3.92 & $100: 0$ \\
\hline & 0.5 & 50.60 & 46.87 & -3.73 & $93: 7$ \\
\hline \multirow[t]{2}{*}{ Tres Piedras North } & 0.4 & 42.95 & 17.11 & -25.84 & $40: 60$ \\
\hline & 0.5 & 50.60 & 17.31 & -33.29 & $34: 66$ \\
\hline \multirow[t]{3}{*}{ Tres Piedras Middle } & 0.3 & 35.30 & 39.76 & 4.46 & $100: 0$ \\
\hline & 0.4 & 42.95 & 37.10 & -5.85 & $86: 14$ \\
\hline & 0.5 & 50.60 & 39.76 & -10.84 & $79: 21$ \\
\hline \multirow[t]{2}{*}{ Tres Piedras South } & 0.5 & 50.60 & 26.48 & -24.12 & $52: 48$ \\
\hline & 0.4 & 42.95 & 26.48 & -16.47 & $62: 38$ \\
\hline \multicolumn{6}{|l|}{ \$7/AUM forage value } \\
\hline Bloomfield & 0.5 & 50.60 & 41.84 & -8.76 & $83: 17$ \\
\hline Cedar Hills & 0.5 & 50.60 & 34.27 & -16.33 & $68: 32$ \\
\hline Gobernador & 0.5 & 50.60 & 35.58 & -15.02 & $70: 30$ \\
\hline Taos & 0.5 & 50.60 & 14.24 & -36.36 & $28: 72$ \\
\hline \multirow[t]{2}{*}{ Navajo City } & 0.4 & 42.95 & 65.62 & 22.67 & $100: 0$ \\
\hline & 0.5 & 50.60 & 65.62 & 15.02 & $100: 0$ \\
\hline \multirow[t]{2}{*}{ Tres Piedras North } & 0.4 & 42.95 & 23.96 & -18.99 & $56: 44$ \\
\hline & 0.5 & 50.60 & 24.23 & -26.37 & $48: 52$ \\
\hline \multirow[t]{3}{*}{ Tres Piedras Middle } & 0.3 & 35.30 & 55.66 & 20.36 & $100: 0$ \\
\hline & 0.4 & 42.95 & 51.94 & 8.99 & $100: 0$ \\
\hline & 0.5 & 50.60 & 55.66 & 5.06 & $100: 0$ \\
\hline \multirow[t]{2}{*}{ Tres Piedras South } & 0.4 & 42.95 & 37.07 & -5.88 & $86: 14$ \\
\hline & 0.5 & 50.60 & 37.07 & -13.53 & $73: 27$ \\
\hline \multicolumn{6}{|l|}{$\$ 10 / A U M$ forage value } \\
\hline Bloomfield & 0.5 & 50.60 & 59.77 & 9.17 & $100: 0$ \\
\hline Cedar Hills & 0.5 & 50.60 & 48.96 & -1.64 & $97: 3$ \\
\hline Gobernador & 0.5 & 50.60 & 50.83 & 0.23 & $100: 0$ \\
\hline Taos & 0.5 & 50.60 & 24.53 & -26.07 & $48: 52$ \\
\hline \multirow[t]{2}{*}{ Navajo City } & 0.4 & 42.95 & 93.74 & 50.79 & $100: 0$ \\
\hline & 0.5 & 50.60 & 93.74 & 43.14 & $100: 0$ \\
\hline \multirow[t]{2}{*}{ Tres Piedras North } & 0.4 & 42.95 & 34.22 & -8.73 & $80: 20$ \\
\hline & 0.5 & 50.60 & 34.61 & -15.99 & $68: 32$ \\
\hline \multirow[t]{3}{*}{ Tres Piedras Middle } & 0.3 & 35.30 & 79.51 & 44.21 & $100: 0$ \\
\hline & 0.4 & 42.95 & 74.20 & 31.25 & $100: 0$ \\
\hline & 0.5 & 50.60 & 79.51 & 28.91 & $100: 0$ \\
\hline \multirow[t]{2}{*}{ Tres Piedras South } & 0.4 & 42.95 & 52.95 & 10.00 & $100: 0$ \\
\hline & 0.5 & 50.60 & 52.95 & 2.35 & $100: 0$ \\
\hline
\end{tabular}

${ }^{1}$ Break-even costs were computed by estimating what total cost (aerial application + chemical cost) would force the net present value of the infinite series $[F(S)]$ to zero, excluding treatment cost. Only forage value was varied. All other economic variables were as defined in Table 1.

$2 \%$ of cost incurred by rancher:\% state, federal, or county government. 
sites with dense stands of sagebrush rarely occurred with a productive understory of grasses and forbs. This may partially explain why New Mexico lies on the periphery of the historic sage grouse distribution range and the species has not been found in the state for many years (Connelly and Braun 1997). Research is needed to further quantify overstory-understory relationships elsewhere across sagebrush rangelands and with additional studies to determine whether reducing the shrub in certain situations would enhance sage grouse habitat values. As Welch (1997) notes, the desirable amount of big sagebrush depends on the perspective and resource values desired.

Net economic returns from big sagebrush control for livestock production has diminished since Sneva (1972) concluded that chemical big sagebrush control brings an exceptional rate of return on investment. In this study, only the most productive sites that realized a substantial forage response were estimated to have positive economic returns from sagebrush control. Cost-share programs are now generally required if livestock producers are to realize positive economic benefits from big sagebrush control. Increasingly, the stated objective for brush control is an upgrade in range and watershed condition and not the additional livestock that might be produced because of the brush control treatment. The economic value of these nonmarket benefits remains elusive and limits the ability to make an overall economic assessment of brush control treatments.

\section{LITERATURE CITED}

Anonymous. 1962. Big sagebrush goes down-grasses come up. Nevada Ranch \& Home Rev., Univ. of Nevada-Reno, 2:15.

Bartlett, E. T., J. W. Bartolome, and T. M. Quigley. 1988. Chapter 6: costs and benefits of the Vale program. In: H. F. Heady [ed.]. The Vale rangeland rehabilitation program: An evaluation. U.S. Dept. of Agr. For. Serv. Resour. Bull. PNW-RB-157.

Bartlett, E. T., L. A. Torell, N. R. Rimbey, L. W. VanTassell, and D. W. McCollum. 2002. Valuing grazing use on public lands. Journal of Range Management 55:426-438.

BASTIAN, C. T., J. J. JACOBS, AND M. A. SMItH. 1995. How much sagebrush is too much: an economic threshold analysis. Journal of Range Management 48:73-80.

Connelly, J. W., and C. E. Braun. 1997. Long-term changes in sage grouse Centocercus urophasianus populations in western North America. Wildlife Biology 3:229-234.

Connelly, J. W., M. A. Schroeder, A. R. Sands, and C. E. Braun. 2000. Guidelines to manage sage grouse populations and their habitats. Wildlife Society Bulletin 28:967-985.

Faustmann, M. 1849. On the determination of the value which forest land and immature stands possess for forestry. English edition edited by M. Gare, Oxford Institute, Paper 42, 1968. Reprinted in Journal of Forest Economics 1(1995):7-44.
Hull, A. C., And G. J. Klomp. 1974. Yield of crested wheatgrass under four densities of big sagebrush in southern Idaho. USDA-ARS Tech. Bull. 1483.

Hүatт, S. W. 1966. Sagebrush control—costs, results, and benefits to the rancher. Journal of Range Management 19:42-43.

Hyder, D. N., and F. A. Sneva. 1956. Herbage response to sagebrush spraying. Journal of Range Management 9:34-38.

Lee, A. C., J. R. Conner, J. M. Muelde, J. W. Richardson, and J. W. Stuth. 2001. Regional cost share necessary for rancher participation in brush control. Journal of Agricultural and Resource Economics 26:478-490.

McDaniel, K. C., D. L. Anderson, and L. A. Torell. 1992. Vegetation change following big sagebrush control with tebuthiuron. Agr. Exp. Sta. Bull. 764. Las Cruces, NM.

McDaniel, K. C., and J. F. Balliette. 1986. Control of big sagebrush (Artemisia tridentata) with pelleted tebuthiuron. Weed Science 34:276-280.

McDaniel, K. C., L. A. Torell, and C. G. OChOA. 2005. Wyoming big sagebrush recovery and understory response with tebuthiuron control. Rangeland Ecology and Management 58:65-76.

OLson, R. J., J. HANSEn, T. Whitson, And K. Johnson. 1994. Tebuthiuron to enhance rangeland diversity. Rangelands 16:197-201.

Pasour, E. C., JR. 1990. Agriculture and the state: Market processes and bureaucracy. New York: Holmes \& Meier Publishers. $258 \mathrm{p}$.

PerRin, R. K. 1972. Asset replacement principles. American Journal of Agricultural Economics 54:60-67.

RoNE, R. G. 2001. A comparison of sediment production on chemically treated and untreated sagebrush rangeland in the Rio Puerco headwaters near Cuba, New Mexico. [M.Sc. thesis.] Socorro, NM: New Mexico Institute of Mining and Technology. $186 \mathrm{p}$.

SneVA, F. A. 1972. Grazing return following sagebrush control in eastern Oregon. Journal of Range Management 25:174-178.

StURGES, D. L. 1983. Long-term effects of big sagebrush control on vegetation and soil water. Journal of Range Management 36:760-765.

Tanaka, J. A., AND J. P. Workman. 1988. Economic optimum big sagebrush control for increasing crested wheatgrass production. Journal of Range Management $41: 172-178$

Torell, L. A., And K. C. McDaniel. 1986. Optimal timing of investments to control honey mesquite. Journal of Range Management 39:378-382.

uS Department of Agriculture/National Agricultural Statistics Service (USDA/ NASS). 2002. Agricultural prices monthly, January 31. Available at: http:// usda.mannlib.cornell.edu/reports/nassr/price/pap-66/. Accessed 7 May 2002.

WatTS, M. J., and C. L. Wambolt. 1989. Economic evaluation of Wyoming big sagebrush (Artemisia tridentata) control methods. Weed Technology 3: 640-645.

WeLCH, B. L. 1997. Comment: big sagebrush pro versus con. Journal of Range Management 50:322-323.

WeSt, N. E., ANd G. F. GIFFORD. 1976. Rainfall interception by cool-desert shrubs. Journal of Range Management 29:171-172.

Whitson, T. D., M. A. Ferrel, And H. P. Alley. 1988. Changes in rangeland canopy cover seven years after tebuthiuron application. Weed Technology 2: 486-489.

Workman, J. P. 1986. Range economics. New York: Macmillan Publishing. 217 p. 